\title{
Fire resistance of extruded hollow-core slabs
}

\author{
Hertz, Kristian Dahl; Sørensen, Lars Schiøtt; Giuliani, Luisa
}

Published in:

Journal of Structural Fire Engineering

Link to article, DOI:

10.1108/JSFE-07-2016-0009

Publication date:

2017

Document Version

Peer reviewed version

Link back to DTU Orbit

Citation (APA):

Hertz, K. D., Sørensen, L. S., \& Giuliani, L. (2017). Fire resistance of extruded hollow-core slabs. Journal of Structural Fire Engineering, 8(3), 324-336. https://doi.org/10.1108/JSFE-07-2016-0009

\section{General rights}

Copyright and moral rights for the publications made accessible in the public portal are retained by the authors and/or other copyright owners and it is a condition of accessing publications that users recognise and abide by the legal requirements associated with these rights.

- Users may download and print one copy of any publication from the public portal for the purpose of private study or research.

- You may not further distribute the material or use it for any profit-making activity or commercial gain

- You may freely distribute the URL identifying the publication in the public portal

If you believe that this document breaches copyright please contact us providing details, and we will remove access to the work immediately and investigate your claim 


\title{
Fire resistance of extruded hollow-core slabs
}

K.D. Hertz, Professor Dept. of Civil Engineering, Technical University of Denmark.

L.S.Sørensen, Associate Professor Danish Building Research Institute, Aalborg University.

L.Giuliani, Associate Professor Dept. of Civil Engineering, Technical University of Denmark.

\begin{abstract}
Prefabricated extruded hollow-core slabs are preferred building components for floor structures in several countries. It is therefore important to be able to document the fire resistance of these slabs proving fulfilment of standard fire resistance requirements of 60 - and 120 minutes found in most national building regulations.
\end{abstract}

The paper presents a detailed analysis of the mechanisms responsible for the loss of load-bearing capacity of hollow-core slabs when exposed to fire.

Furthermore, it compares theoretical calculation and assessment according to the structural codes with data derived from a standard fire test and from a thorough examination of the comprehensive test documentation available on fire exposed hollow-core slabs.

Mechanisms for loss of load-bearing capacity are clarified, and evidence of the fire resistance is found.

For the first time the mechanisms responsible for loss of load-bearing capacity are identified and test results and calculation approach are for the first time Applied in accordance with each other for assessment of fire resistance of the structure.

Key-words: extruded hollow-core slabs, fire test, standard fire resistance, load-bearing capacity 

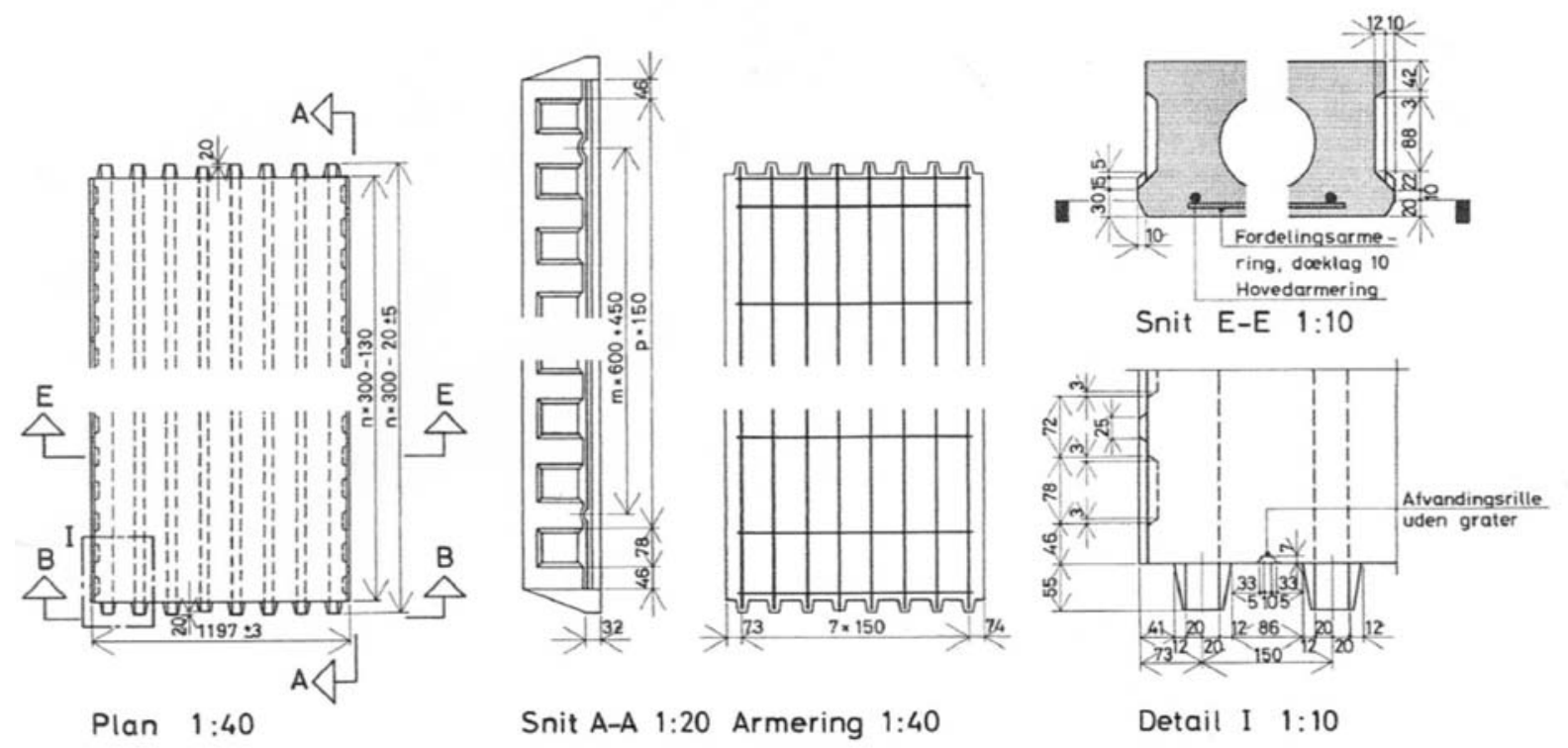

Figure 1. A classic hollow-core slab with slack main reinforcement and transverse reinforcement in the bottom flange [1].

\section{Introduction}

A hollow-core slab is a concrete slab with longitudinal holes or channels. It was developed in the 1960'ies as a deck element for industrialized buildings. The holes made it light and suitable for being lifted in place with a crane, but the hollow, light design also caused some negative effects in terms of poor sound insulation, rigid rectangular lay-out of the buildings, and doubts about the fire resistance.

The production methods for hollow-core slabs have developed in time. They are still slabs with holes, and therefore called hollow-core slabs, but the reinforcement lay-out, the reinforcement quality, and the concrete quality have changed, as well as the geometry of the joining grooves at the ends and at the sides of the elements.

In time the concept of hollow-core slabs has covered at least 4 different structural designs with different standard fire resistance before the present day extruded slabs:

The original classic hollow-core slabs were $0.6 \mathrm{~m}$ or $1.2 \mathrm{~m}$ wide with holes made by means of mandrels pressed into the concrete from both ends of the element.

These classic hollow-core slabs were dominant at the beginning. Their geometry and reinforcement are seen on Figure 1 from Nissen [1]. They had slack deformed bars as main reinforcement in the longitudinal direction and slack transverse reinforcement in the bottom flange. This means that the bottom flange under the holes was reinforced across the element, improving the ability to keep the bottom flange in place and transferring horizontal shear. 
Then a production started of $1.2 \mathrm{~m}$ wide hollow-core slabs with slip form casting. These slabs had pretensioned reinforcement lines and were produced with slack transverse reinforcement in the bottom flange.

After that, a production started of $1.2 \mathrm{~m}$ wide extruded hollow-core slabs with pretensioned reinforcement. Extruded prestressed deck elements have no transverse reinforcement, and a moving machine presses a relatively dry concrete in shape around mandrels forming the holes.

Lately, around 2010, a number of factories increased the width of the extruded decks to $2.4 \mathrm{~m}$ still without application of transverse reinforcement.

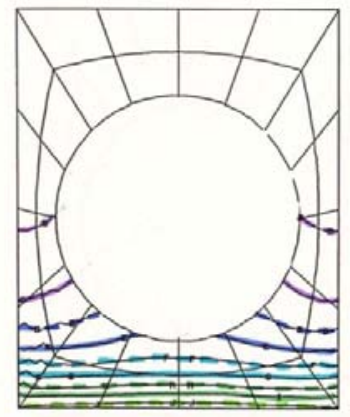

$30 \mathrm{~min}$

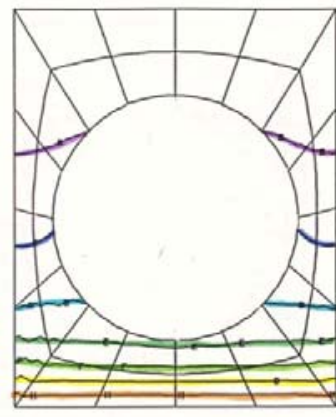

$60 \mathrm{~min}$

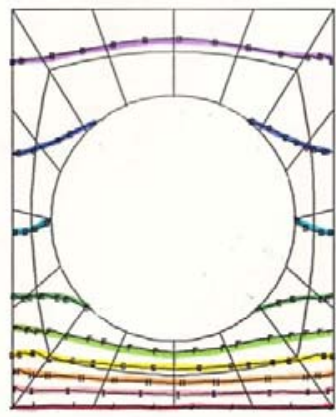

$100 \mathrm{C}$

$100 \mathrm{C}$

$200 \mathrm{C}$

$400 \mathrm{C}$ $600 \mathrm{C}$

$90 \mathrm{~min}$

Figure 2. An early example calculation of an isotherm pattern by a 2D FEM analysis.

\section{Previous investigations}

A number of research results are available on fire exposed hollow-core slabs. An early analytical 2D FEM approach by Poulsen and Schirmacher [2] dealt with the temperature distribution of an original hollow-core slab under the precondition of an unbroken bottom flange (Figure 2).

Integrity of the bottom flange is often assumed for calculating the load-bearing capacity of hollow-core slabs in practise, and results from the corresponding thermal calculations are applied for design, where the isotherms becomes horizontal after 60 minutes like in a massive slab.

This is because the transfer of heat in the holes changes from being lower than for massive concrete, due to initial insulating effect of the air in the holes, to be higher, due to increased radiation through the holes. The precondition of horizontal isotherms is therefore only valid around 60 minutes standard fire and only if the integrity of the bottom flange is considered intact. 


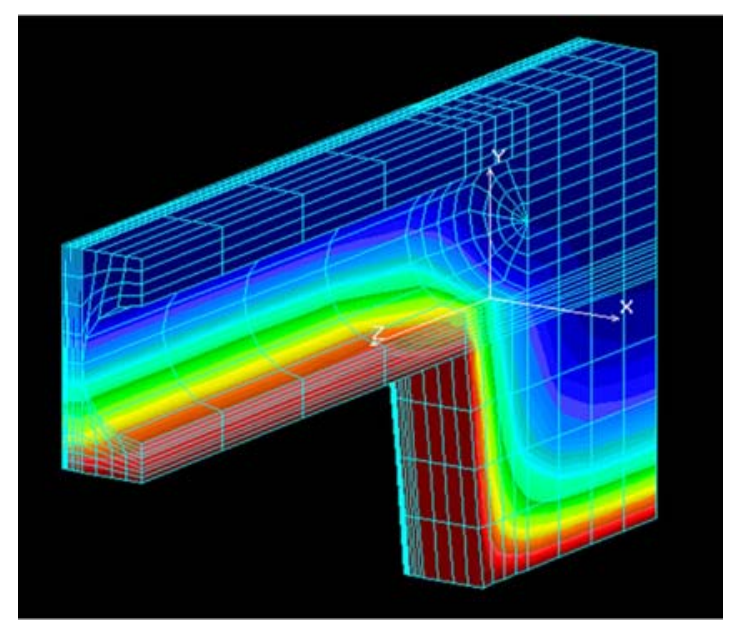

Figure 3. Illustration of a temperature pattern from a 3D FEM analysis at a support.

More recent 3D FEM calculations like the one in Figure 3 (Meaouia [3]) show the same pattern. But in addition, they show temperature distribution at the supports needed for assessment of anchorage properties.

In the mid 2000's a fire part of the Eurocode for concrete structures EN1992-1-2 [4] has been introduced based on previous work $[5,6,7]$ that together with [8] established a basis for calculation of fire exposed concrete structures. Furthermore, a product code for hollow-core slabs EN1168 $[9,10]$ was published, which referred to the chapters 4.2, 4.3, and to Annex B of the EN1992-1-2 [4] with respect to assessment of fire resistance.

Tests of hollow-core slabs with $2.4 \mathrm{~m}$ span between inlayed steel beams are reported by Borgogno and Fontana [11[, [12], and a PhD thesis (Fellinger [13]) dealt with calculation of shear and anchorage of fire exposed hollow-core slabs. The results of the calculations are compared to tests from various sources, and crack patterns are shown for slender slab-beams consisting of two ribs and one hole.

Shear resistance was also the subject for Van Acker [14], where 4 tests were made for shear resistance on specimens with $3 \mathrm{~m}$ span.

In 1999 Andersen and Lauridsen [15] published 3 fire tests each with two $1.2 \mathrm{~m}$ wide extruded hollow-core slab elements side by side with $6 \mathrm{~m}$ span and thicknesses of 185 $\mathrm{mm}, 220 \mathrm{~mm}$, and $270 \mathrm{~mm}$.

Previous to the tests a board of experts was invited to calculate the fire resistance of the slabs, which was generally found to be about 60 minutes for all 3 slabs, corresponding to the assumption that the integrity of the bottom flange was intact and the temperatures could be calculated for a massive cross-section.

However, the test results were 21 minutes, 26 minutes, and 21 minutes fire resistance. 


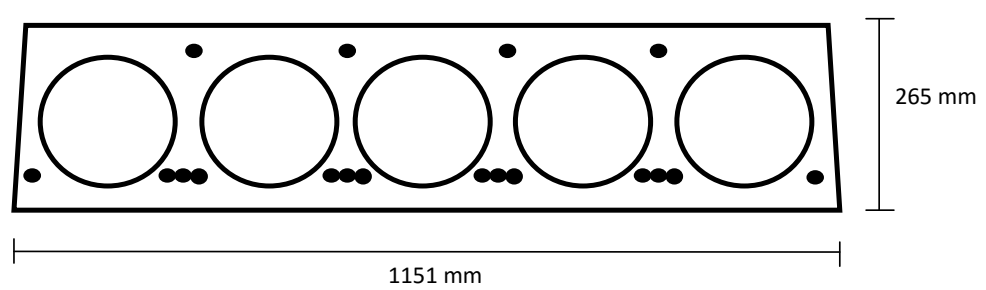

Figure 4. Cross section of extruded hollow-core slab.

\section{New test of extruded hollow-core slabs}

The results of Andersen and Lauridsen [15] started a debate on the fire resistance of hollow-core slabs in Denmark, but the deviations from the calculated results were not immediately explained.

The Danish minister of commerce insisted that a new test should be made.

This was made in 2004 by the Danish Institute of Fire Technology on two $265 \mathrm{~mm}$ thick and $1.2 \mathrm{~m}$ wide extruded hollow-core slabs with geometry as seen in Figure 4.

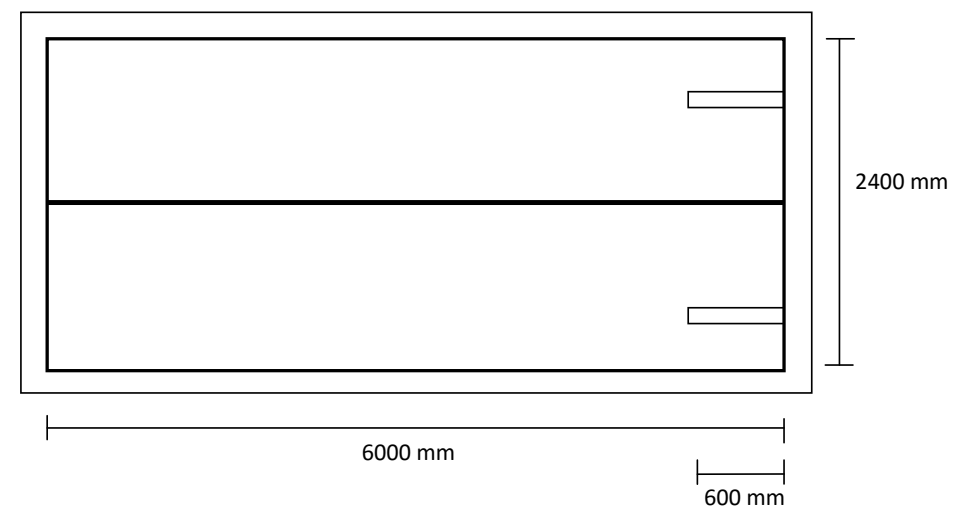

Figure 5. Arrangement of two floor elements in a surrounding frame.

The elements had a span of $6 \mathrm{~m}$ between the supports. The groove between the elements was cast out, and the elements were cast into a surrounding frame (Figure 5). The one end of each element was rigidly connected to the frame by casting a $600 \mathrm{~mm}$ long reinforcing bar into an opened hole. The concrete quality was $55 \mathrm{MPa}$, and each element was pretensioned by 14 lines in the bottom and 4 at the top, where each line was $12.5 \mathrm{~mm}$ with characteristic tensile strength $1770 \mathrm{MPa}$. Each element was loaded by 2 pointed loads of $35 \mathrm{kN}$ at $1.783 \mathrm{~m}$ from the rigid connected end and 2 of $27 \mathrm{kN}$ at $1.782 \mathrm{~m}$ from the other. 


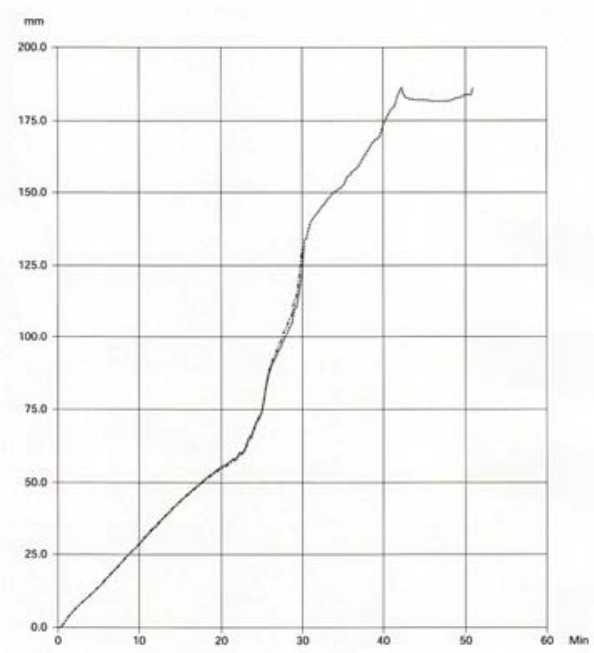

Figure 6. Deflections measured from start of loading.

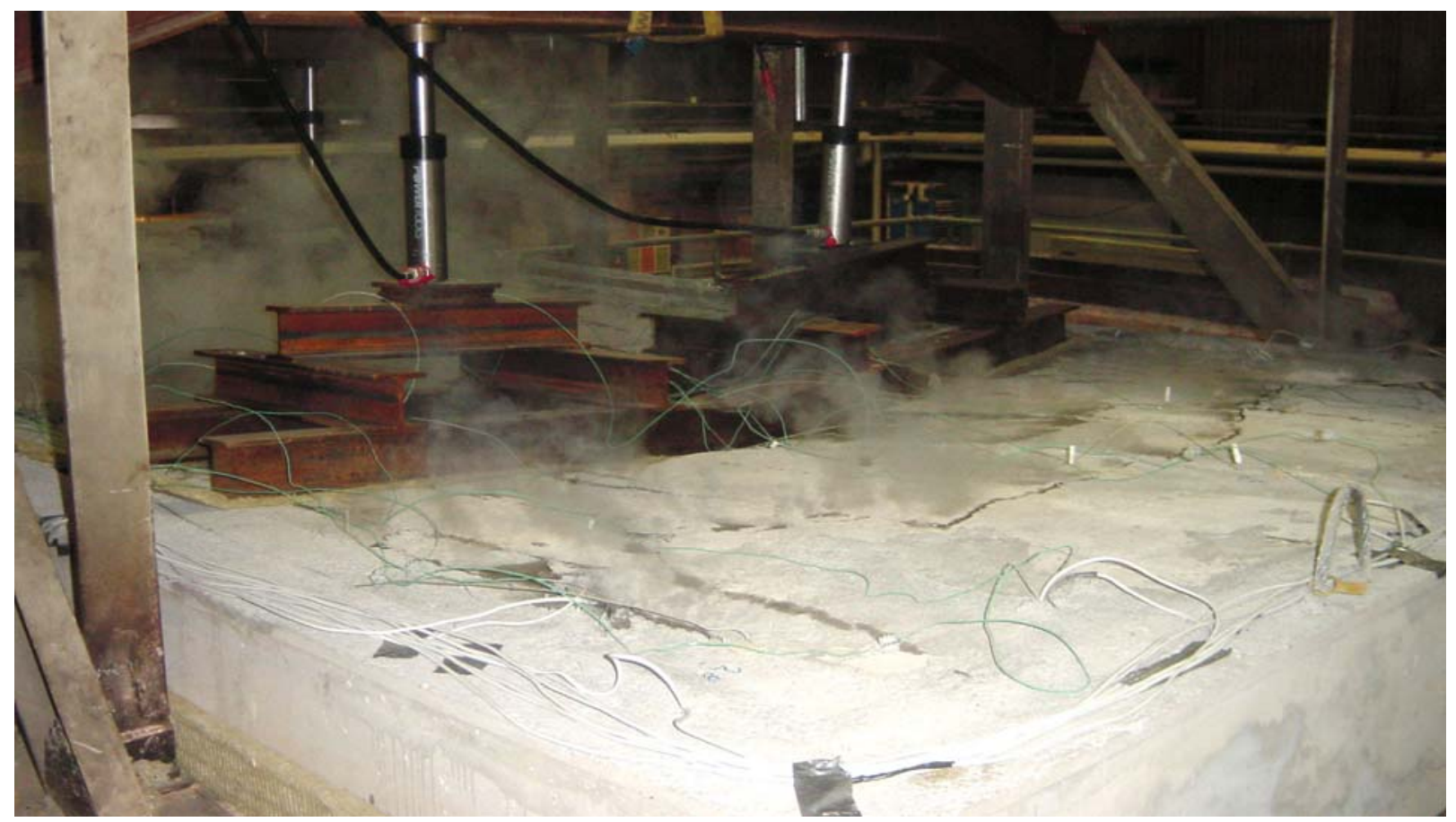

Figure 7. Cracks in top flange after approx. 15 min. Photo K. Hertz.

The midspan deflections are given in Figure 6. Substantial cracks were developed in top and bottom of the slab elements after 15 minutes (Figure 7), and the ISO 834 standard fire duration was assessed to be 25 minutes at this accredited test. 


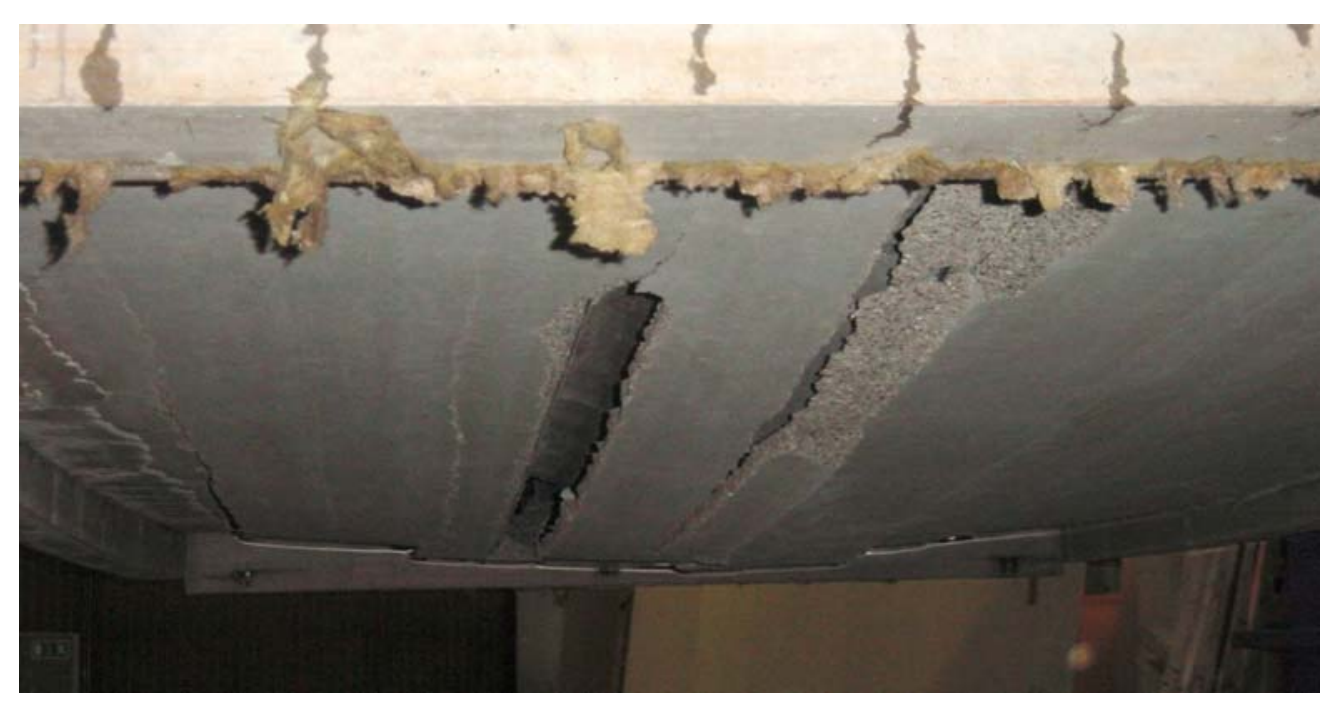

Figure 8. Damages after 25 minutes. Photo K. Hertz.

Lifting the element off the oven, it was seen that the bottom flange was partly fallen down and large cracks were developed to the other channels (Figure 8). No sign of shear failure was seen and the deflection indicated that the failure mode may have been bending. But as explained in the following, the failure modes of shear, anchorage, bending, and de-lamination may be results of the same deterioration of the slab.

\section{Modified calculations}

From the tests reported and from personal observations of the authors at actual fires it is seen that the integrity of the bottom flange is a problem especially for extruded hollow-core slabs.

Cracks appear along the decks under the channels after 10-15 minutes fire exposure and often the bottom flanges falls down, as shown for example in Figure 8.

Hot gas may enter the holes of the deck, and the webs between the holes become threesided exposed, so that the increase in temperature in the webs and in the main reinforcement happens faster than assumed by a calculation of a massive slab.

This explains why the theoretically assessed fire resistance times for the tests reported by Andersen and Lauridsen [15] did not fit with the test results.

It also explains why the fire test from 2004 reported in this paper also gave 25 minutes fire resistance even though the slab was supported by a surrounding frame. 


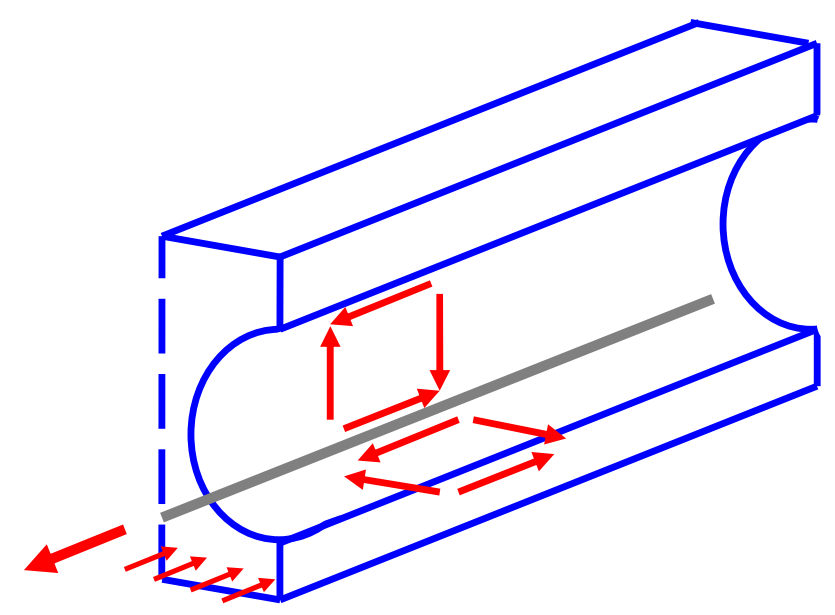

Figure 9. Shear stresses in web and bottom flange.

However, a debate has been going on from the assumption that shear should be the main problem for fire exposed hollow-core slabs, and tests have been made on short elements in order to document the shear resistance.

Nevertheless, a short element cannot develop the same bending induced horizontal shear between web and the bottom flange beneath the longitudinal holes, as a long element (Figure 9). The mechanical and the thermal deflections are not the same for a short as for a long element. It is therefore obvious that a test of a short element cannot show the same effect of loss of integrity of the bottom flange, and such a test can therefore not document how the shear resistance of the web between the holes is affected in a longer hollow-core slab exposed to fire.

This explains why tests made on short elements as for example Van Acker [14] might show better performance than if the tests were made on long elements.

Failure modes caused by loss of integrity of the bottom flange may be shear as well as anchorage, bending, or de-lamination, because all these failure modes are affected by the heating from the holes and the crack formation in bottom flange and in the webs between the holes.

A more precise calculation method that takes into account the simultaneous effects of bending, thermal gradients, thermal deformation, mechanical deflection, and horizontal shear stress in the bottom flange for horizontal distribution of force from the web into the flange does not exist.

If it emerges, it will require a considerable experimental documentation to validate it, because it should verify that all aspects are taken into account correctly. 
EN1168

Product Standard

Annex G

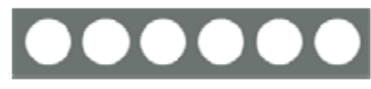

EN1992-1-2

Concrete Structures

$4.2+4.3+$ Annex B

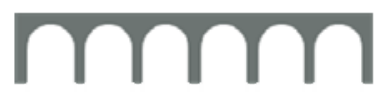

Figure 10. Reduced cross-section for simplified calculations.

Due to the short time before the integrity of the bottom flange is lost, a reasonable simplified calculation will be to omit the bottom flange at the holes and consider the ribs between the holes as exposed by fire from 3 sides from the beginning of the fire as shown in Figure 10.

A formal calculation according to the product standard EN1168 ([9] and [10]) refers to 4.2, 4.3, and to Annex B in the Eurocode for concrete structures EN 1992-1-2 [4]. Annex B consists of two methods for calculating a reduced cross-section: method B1 was originally written by Yngve Anderberg and is based on removing material outside the $500^{\circ} \mathrm{C}$ isotherm; method B2, which is considered slightly more accurate, was originally written by Kristian Hertz. The two methods give much the same result when used on hollow-core slabs.

Figure B5b in EN 1992-1-2 [4] (Figure 11) shows that the damaged zone $a_{z}$ for a slab with a thickness of $150-250 \mathrm{~mm}$ is $36 \mathrm{~mm}$ after a 120 minutes standard fire and $20 \mathrm{~mm}$ for a 60 minutes standard fire. This means that the bottom flange of a hollow-core slab, which is usually about $34 \mathrm{~mm}$ thick, will be completely covered by the damaged zone after 120 minutes and the majority of it after 60 minutes. This means that the reduced cross-section to be considered according to concrete code EN 1992-1-2 [4] is a ribbed cross-section, because the damaged unreinforced bottom flange cannot be taken into account under the holes, where there is nothing to support it (Figure 10).

The same conclusion follows directly from principle 4.5.2 (1)P in [4] saying that the possibility of a detachment of the bottom concrete should be taken into account.

According to the latest version of the hollow-core product standard EN1168 [9] from 2011 , temperatures in the cross section can be calculated under the assumption of a massive slab. As mentioned above, this approach was made for hollow-core slabs with a sufficiently reinforced bottom flange at 60 minutes standard fire resistance. The product standard does not distinguish between the different kinds of hollow-core slabs, but it claims to be based on the concrete code.

Therefore, you must observe that especially for an extruded hollow-core slab the fire design model is not a hollow-core slab but a ribbed cross-section that cannot be assessed by the massive slab assumption of EN1168 [9]. 


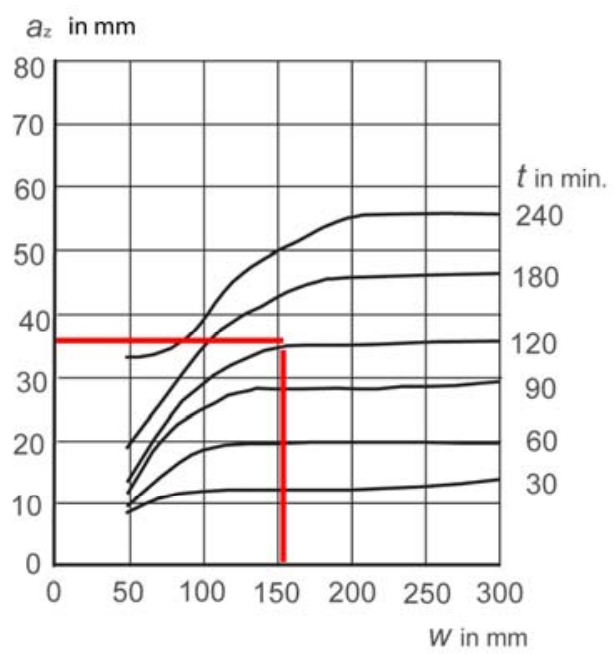

Figure 11. Damaged zone in mm after 120 min (fig B5b in EN1992-1-2).

The prestressing tendons in an extruded hollow-core slab will often have a depth to the centre line of $34 \mathrm{~mm}$. A finite difference temperature calculation as Confire [16] of the temperature of a prestressing tendon with cover $34 \mathrm{~mm}$ from the bottom in an $80 \mathrm{~mm}$ thick web gives $444^{\circ} \mathrm{C}$ after 30 minutes of a standard fire, where the $0.2 \%$ yield strength of a cold-drawn prestressing wire is reduced to $25 \%$ of its original value and the load-bearing capacity in bending must be regarded as insufficient.

If the temperature were instead assessed by figure A3 in the Eurocode [4], a temperature of $420^{\circ} \mathrm{C}$ would be obtained (Figure 12).

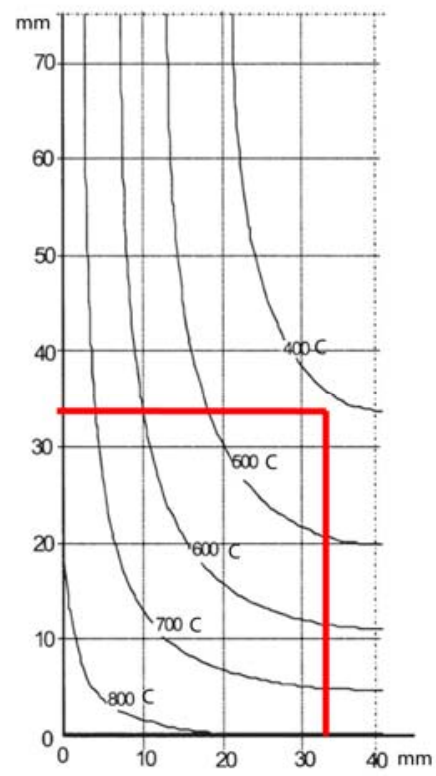

Figure 12. Temperature after $30 \mathrm{~min}$ in depth $34 \mathrm{~mm}$ (fig A3 in EN1992-1-2). 
Furthermore, the prestressing tendons and their cover thickness will be comprised by the damaged zone, and the structural code cannot be used to document interaction between the reinforcement and the element (for example [8]).

In the example above the average compressive strength through the concrete web at 30 minutes is found to be $17 \%$ of the original, which explains the de-lamination failure for example seen in the fire, discussed below.

The shown calculation assessment and the alternative application of the Eurocodes both give a fire resistance time of approximately 30 minutes for ordinary design loads. This seems to correspond well with the fire resistance time found from tests of extruded hollow core slabs as described previously and below, and it is seen that bending, shear, anchorage, as well as de-lamination are possible failure modes depending on the actual geometry and load.

\section{The Holco-fire project}

In 2007 a car park building fire in Rotterdam caused a number of hollow-core slabs to de-laminate and partially fall down Feijter [17].

In the Netherlands it is common to apply in-situ cast top concrete to improve the performance of hollow-core slabs for example in order to fulfil the acoustic requirements.

Doing so, the top concrete and the top flange may act as a stiff massive slab without the thermal gradient that develops in the bottom flange of the hollow-core slab, when it is fire exposed. The bottom flange will therefore tend to deflect more than the stiff top slab, giving rise to tensile stresses in the webs between the holes. These stresses may cause splitting of the webs and de-lamination of the element, so that the bottom half of the slab falls down.

The top flange of the hollow-core elements in Rotterdam was reinforced and so was also the in-situ cast top concrete. The remaining top flange and top concrete therefore constituted a reinforced massive slab that in this case could carry the limited load on the deck so that only the bottom half fell down and the floor as such did not collapse.

The Rotterdam fire caused a debate about fire resistance of hollow-core slabs in the Netherlands, and a project was initiated by hollow-core slab producers to provide a convincing and final documentation for the fire resistance.

In 2014, the International Prestressed Hollow-core Association (IPHA) published the report of this so called Holcofire project Jansze [18]. 
The report gives a list of 162 fire tests performed between 1966 and 2010, in order to present the available test documentation.

The main author of the report declares in a paper Jansze [19] that no more tests are needed, and that the project once and for all proves that hollow-core slabs have excellent fire properties.

Unfortunately, the report does not distinguish between the various kinds of tested hollow-core slabs. The associated test reports are not enclosed and usually not available, so it is not possible for the reader to know how the slabs are made, the geometry of the cross-section, the reinforcement, the test setup, the support conditions, or the loading.

However, the HolcoFire report [18] gives an overview of the tests in a table.

The table shows that a number of tests were made on slices of hollow-core slabs, on very narrow elements, and on systems of beams and decks. Furthermore, some tests were made on decks with fire insulation at the bottom, with concrete topping, with reduced holes, or with deck thicknesses or cover thicknesses larger than commonly used. In this survey we therefore exclude tests for deck thicknesses $>350 \mathrm{~mm}$ or cover thicknesses $>50 \mathrm{~mm}$.

Especially, a large number of tests were made on decks with short spans even down to a length of only $150 \mathrm{~mm}$, so that the decks were not loaded in bending and thermal deflection and horizontal shear in the flanges was limited or not existing. These tests violate the minimum requirement of 4 meter length prescribed for fire resistance tests by the product standard for hollow-core slabs EN1168 [9].

\begin{tabular}{|c|c|c|c|c|c|c|c|c|c|c|c|c|c|}
\hline $\begin{array}{l}\text { Holco } \\
\text { test \# }\end{array}$ & Fire test name & $\begin{array}{l}\text { Test } \\
\text { year }\end{array}$ & $\begin{array}{c}\text { Slab } \\
\text { depth } \\
{[\mathrm{mm}]}\end{array}$ & $\begin{array}{c}\text { Topping } \\
{[\mathrm{mm}]}\end{array}$ & $\begin{array}{c}\text { Slab } \\
\text { width } \\
{[\mathrm{mm}]}\end{array}$ & web & $\begin{array}{c}\text { Strand } \\
\mathrm{mm} 2 / \text { slab }\end{array}$ & $\begin{array}{l}\text { Axis } \\
\text { dist } \\
\mathrm{mm}\end{array}$ & $\begin{array}{l}\text { Length } \\
\text { of test } \\
\text { slab m } \\
\end{array}$ & $\begin{array}{c}\text { Width } \\
\text { test set- } \\
\text { up m }\end{array}$ & $\begin{array}{c}\text { No. } \\
\text { Of } \\
\text { slabs }\end{array}$ & $\begin{array}{c}\text { Test } \\
\text { set- } \\
\text { up }\end{array}$ & $\begin{array}{l}\text { Time } \\
\text { [min] }\end{array}$ \\
\hline H96 & DIFT X52650d & 1998 & 185 & 0 & 1197 & 336 & 416 & 30 & 6.2 & 2.4 & 2 & SYS & 21 \\
\hline H97 & DIFT X52650e & 1998 & 220 & 0 & 1197 & 336 & 416 & 30 & 6.2 & 2.4 & 2 & SYS & 26 \\
\hline $\mathrm{H} 98$ & DIFT X52650f & 1998 & 270 & 0 & 1197 & 336 & 930 & 32 & 6.2 & 2.4 & 2 & SYS & 21 \\
\hline $\mathrm{H} 137$ & IBS 07012911 & 2004 & 160 & 0 & 1200 & 259 & 468 & 48 & 5 & 3.6 & 3 & SYS & 94 \\
\hline H138 & DIFT PG 11304 & 2004 & 265 & 0 & 1200 & 238 & 930 & 40 & 6.065 & 2.4 & 2 & SYS & 25 \\
\hline H139 & ZAG 160/04-530 & 2004 & 320 & 0 & 1200 & 288 & 1209 & 35 & 5.12 & 2.4 & 2 & SYS & 105 \\
\hline
\end{tabular}

Table 1. Relevant fire tests performed on hollow-core slabs since 1994. Tests of known load, reinforcement, and geometry are boxed. 


\section{Test Results}

If tests with decks shorter than 4 meters are deselected together with those tests that for the other above mentioned reasons are irrelevant, a systematic review of the tests shows that only 4 out of the 162 tests (H3, H50, H78, H79) have been tested for 120 minutes, but all these are more than 20 years old and with unknown construction, load, and support conditions.

As explained, very different methods of production have been used over time to manufacture hollow-core slabs and the hollow-core slabs applied today are typically produced by extrusion, which does not allow for transverse reinforcement in the bottom flange. It is therefore obvious that the documentation presented by the Holcofire project report is partly based on slabs with cross-reinforcement in the bottom flange, and the results for these are not applicable as documentation of fire resistance of the extruded hollow-core slabs.

By analyzing the data presented, it is found that only 6 relevant fire tests of hollowcore slabs (H96, H97, H98, H137, H138, and H139) have been performed within the last 20 years.

None of these tests, reported in Table 1 demonstrated a fire resistance of 120 minutes. Four of these tests (boxed in Table 1) were made at the Danish Institute of Fire Technology and yielded a fire resistance between 21- and 26 minutes (H96, H97, H98, H138).

The two residual tests show a fire resistance of 94 and 105 minutes. Nevertheless, these slabs are of unknown geometry, reinforcement, support conditions, and load, and a variation of one or more of these conditions may very well give rise to the difference of the results.

\section{Conclusion}

Extruded hollow-core slabs are made without transverse reinforcement in the bottom flange across the holes, and this is one reason why they cannot be compared with the classic hollow-core slabs for which we have about 50 years experience.

A fire test of extruded hollow-core slabs is made and the fire resistance time obtained was 25 minutes.

From this test and from other tests reported in the literature as well as from real fires we know that cracks are formed in the bottom flange of extruded hollow-core slabs and sometimes the bottom flange falls down. 
Calculations and assessments according to the product standard EN1168 with reference to EN 1992-1-2 show that the bottom flange does not preserve its integrity for cross-sections of extruded hollow-core slabs. The calculation model according to the Eurocodes therefore becomes a ribbed cross-section.

Calculations using this model accord well with findings from the full-scale test presented in this paper and the tests presented by the produces in the HolcoFire report.

Neither calculations nor tests are found to document a fire resistance of for example 120 minutes for extruded hollow-core slabs.

Tests and analyses indicate that positive evidence can be found for a fire resistance of about 25 minutes.

\section{References}

[1] Nissen H (1970) Modul og montagebyggeri. Polyteknisk Forlag 429p.

[2] Poulsen A, Schirmacher I (1987) Fire exposed hollow-core slabs. Final project. DIA-B Danish Engineering Academy.

[3] Meaouia K C (2002) Details for fire exposed concrete structures. Final project.Dept. of Civil Engineering, Technical University of Denmark, 66p.

[4] EN 1992-1-2 (2004) Design of concrete structures - Part 1-2:

General rules -Structural fire design. 97p.

[5] Hertz K D (1985) Analyses of Prestressed Concrete Structures Exposed to Fire. Report No.174. Institute of Building Design, Technical University of Denmark. Lyngby, 154p. Presented at the CIB W14 conference in Kyoto. June 1988CIB W14/85/9 (DK).

[6] Hertz K D (2005) Concrete Strength for Fire Safety Design. Magazine of Concrete Research Vol.57, No.8, pp.445-453.

Thomas Telford Ltd. October 2005.

[7] Hertz K D (2004) Reinforcement Data for Fire Safety Design Magazine of Concrete Research Vol.56, No.8, pp.453-459. Thomas Telford Ltd. 
Hertz K D (1982) The Anchorage Capacity of Reinforcing Bars at Normal and High Temperatures. Magazine of Concrete Research Vol.34, No.121, pp.213-220.

[9] EN 1168 (2005 and 2011) Precast concrete products - Hollow core slabs. European Committee for Standardization, 81p.

[10] CEN TC299/WG1/TG1/AdHoc Group Fire (2009) EN1168 Annex G Background document, Fire resistance of prestressed hollow core floors. $45 \mathrm{p}$.

[11] Borgogno W, Fontana M (1996) Versuche zum Tragverhalten von Betonhohlplatten mit flexibler Auflagerung bei Raumtemperatur und Normbrandbedingungen. Institut für Baustatik und Konstruktion, ETH, Zürich, 248p.

[12] Borgogno W (1997) Tragverhalten von Slim Floor Decken mit Betonhohlplatten bei Raumtemperatur und Brandeinwirkungen. Institut für Baustatik und Konstruktion, ETH, Zürich, 108p.

[13] Fellinger J H H (2004) Shear and Anchorage Behaviour of Fire Exposed Hollow-Core Slabs. Probefschrift. Delft University Press, 261p.

[14] Acker A Van (2003) Shear resistance of prestressed hollow-core floors exposed to fire. Structural Concrete Vol.4 No.2, pp. 65-74.

[15] Andersen N E, Lauridsen D H (1999) Hollow-Core Concrete Slabs. Technical Report X52650 Danish Institute of Fire Technology, 30p.

[16] Hertz K D (2012): Users guide for the program Confire. 2. Edition. Technical University of Denmark. 23p.

[17] Feijter M P de (2007), A.J. Breunese: Onderzoek brand parkeergarage Lloydstraat, Rotterdam. Efectis Nederland BV 51p.

[18] Jansze W, et al. (2014) Structural behaviour of prestressed concrete hollow core floors exposed to fire. 226p. BOXPress,.

[19] Jansze W (2014): Extensive research confirms the safety of hollow-core floors under fire. CPI Concrete Plant International. No. 4 pp 38-42. 